\title{
Access by Part-Time Students: A Question of Openness in Canadian Universities
}

\section{GORDON THOMPSON ${ }^{*}$ \& LARRY DEVLIN†}

\begin{abstract}
Canadian universities employ a variety of methods to increase access, especially for adult students unable to attend regular day classes because of employment or family commitments. How effective are such methods? Is the large increase in part-time enrolment during the past twenty-five years due to such policies and practices?

This study examines the evening credit programs of seven middle-size to large universities. Such programs can be viewed as one specific method by which institutions attempt to implement the general organizational value of "openness." In particular, an effort is made to trace the effect on access of two different approaches to the internal organization and administration of evening sessions at the institutions studied. Policies and practices which facilitate parttime study are also discussed.

The paper is exploratory and does not attempt to offer definitive conclusions. Nonetheless, suggestions are offered for further research and for institutional practices which promote part-time study.

The issue of accessibility for part-time students is expected to become of increasing concern in the light of predictions that the traditional student body - those 18-22 years old who predominantly register for full-time study in daytime courses - will decline in the 1990s.

Additionally, universities will be required to accommodate large numbers of adult learners returning for further studies and training as a lifelong learning or recurrent education model is developed by society. The importance of such a model continues to receive attention at both federal and provincial levels in Canada.
\end{abstract}

\footnotetext{
* University of Saskatchewan

$\dagger$ University of Victoria
} 


\section{Résumé}

Les établissments universitaires canadiens utilisent divers moyens pour promouvoir l'accessibilité aux études, particulièrement auprès des clientèles adultes qui à cause d'obligations professionnelles ou familiales ne peuvent bénéficier de la programmation académique de jour. Ces méthodes sont-elles efficaces? Et l'augmentation massive des clientèles à temps partiel résulte-t'elle des efforts délibérés de promotion mis en place par les établissements?

Cette étude examine les programmes crédités offerts en soirée par sept (7) établissements de moyenne et de grande taille. On suggère comme hypothèse que ces programmes représent pour les établissements un moyen de promouvoir la valeur organisationelle "d'ouverture" aux clientèles non traditionnelles. En particulier, on tente d'évaluer les effets sur l'accessibilité de deux modèles d'organisation interne et d'administration des programmes du soir observés dans ces institutions. Les politiques générales et les pratiques de promotion des études à temps partiel sont également abordées.

Cette analyse se veut avant tout exploratoire et ne tente pas d'apporter des réponses définitives aux questions posées. Par ailleurs, elle permet de suggérer certaines voies de recherche privilégées et certaines pratiques institutionelles visant à promouvoir les études à temps partiel.

\section{Introduction}

After thirty years of growth and expansion, the Canadian system of postsecondary education has been described as "extensive, diversified, open and complex" (Fortin, 1987, p. 70). "Openness" and "accessibility" were identified as two major operating principles for Canadian universities in the twenty-first century at the National Forum on Postsecondary Education held in October 1987. The concept of "access" is also a central policy element in recent federal and provincial initiatives (Segal, 1990).

The contemporary university in North America is being urged to re-examine its mission so that research and professional knowledge can be made more widely available to an external public seeking the knowledge, skills and values necessary for career and personal competence in a fluid environment. The modern university "...should become involved as much in the aggregation, interpretation, dissemination and application of existing knowledge as in the quest for new knowledge" (Lynton \& Elman, 1987, p. xi). The principle of access is central to such directions.

However, specific methods of implementing this principle are seldom examined closely. "The postsecondary system in Canada is usually regarded as 
open and accessible but in a passive way. Openings exist; individuals have only to fill them-subject to certain conditions" (Fortin, 1987, p. 95). Indeed, an extensive literature in Canada, the United States and Great Britain, suggests that universities are not as open to qualified adult learners, in particular, as they could be (Tight, 1982; Neilson \& Gaffield, 1986). The special problems of working adults or those in career change were recognized at the 1987 Forum. Even in the community college system of Canada, recent evidence on accessibility by a general adult audience has been described as "mixed" (Levin \& Dennison, 1989, p. 55).

If Canadian universities are "open" and "accessible," as is often suggested by individual institutions, and if these two broad directions are to become primary goals in the twenty-first century, then studies of special access routes and methods are important. Cameron (1978), for example, suggests that "system openness and community interaction" is one of nine major criteria by which the effectiveness of universities as organizations can be measured. System openness was defined as "the emphasis placed on interaction with, adaptation to and service in the external environment" (p. 614).

One general measure of openness is the extent to which universities accommodate degree completion on a part-time basis (Cameron, 1978). Parttime students are significantly older than full-time students and a majority have family or occupational responsibilities. Further, the average age of part-time undergraduate students increased between 1974-75 and 1983-84 (Canadian Organization of Part-time University Students, 1987). In short, they are adult members of the wider community which universities are being asked to serve. Special programs for adults or mature students are an identifiable goal of Canadian universities as organizations (Konrad \& McNeal, 1984).

Between 1965 and 1985, part-time enrolment in Canada increased by $300 \%$ while full-time enrolment increased by $179 \%$ (Anisef, 1989). Such data are often cited as evidence of openness. However, a critical question is whether the disproportionate increase in part-time students is because of or in spite of organizational conditions intended to facilitate access. For example, it has been noted that the availability of degree programs for part-time students is both limited and restricted at many institutions (Canadian Organization of Part-time University Students, 1987). Adult learners often encounter indifference to their problems on Canadian campuses and seldom receive the full measure of academic and administrative services available to younger, full-time students (Campbell, 1984, p. 41). Thus gross changes in registration patterns should not be assumed to provide a valid measure of access or openness without further 
analysis. This question is raised only rarely. Indeed, as Anisef (1985) observed, the research concerning part-time adult students is limited (p. 214).

Although the concepts of "openness" and "access" are relatively new metaphors in higher education, Canadian universities have long maintained special access routes for students unable to fit traditional timetable patterns or university terms. Extra-mural work was begun in 1880 at Queens, which also established the first Summer Session in Canada, in 1910, to serve teachers completing degrees while employed (MacInnes, 1963). Evening, weekend, and offcampus courses have also been used historically by most universities as mechanisms for remaining "open" to the community. The growing use of distance education delivery can be viewed as another attempt by universities to provide access to their curricula. At present, more than twenty-five conventional universities in Canada employ a range of distance education methodologies to deliver individual courses or entire degree programs off campus (Secretary of State, 1989).

The examination of university practices which are designed to serve an external, adult audience thus has significance for questions at both the operational and the macro level of institutions. For example, there is a lengthy literature in both Canada and the United States which treats the operational questions of whether special access routes such as evening and summer sessions should be coordinated centrally within the University as an organization or simply administered as extensions of regular Faculty operation for purpose of academic planning and timetable construction (Lynton \& Elman, 1987). Individual Canadian universities have examined this question repeatedly during the past two decades and continue to do so.

From the perspective of organizational theory, proponents of a decentralized approach suggest that acceptance of "access" as an operating value of institutions would be enhanced if core faculty and line officers of academic units had responsibility for planning and staffing of special sessions whose purpose was to facilitate system openness. Alternately, it can be argued that external adult students have special needs that cannot be accommodated by the simple extrapolation of administrative and academic procedures which were designed in large part to serve a younger, full-time audience.

The efficiency and effectiveness of different approaches to enhancing academic access to universities are more than operational issues. At the macro level, the question is how such programs fit emerging social and government expectations for revised roles of universities in the twenty-first century. Anisef (1989) and others note the need for closer examination of all issues associated with these questions. 


\section{Purpose}

The purpose of this paper is to examine one operational measure of opennessthe organized provision of evening credit courses for students who can only study on a part-time basis. In particular, the paper attempts to identify the effect on access of a decision to decentralize the organization and administration of evening courses offered during the Regular Academic Session (SeptemberMarch). In brief, "decentralization" involved the transfer of responsibility for the administrative coordination of evening hour courses (including budgeting, timetabling, student advising, etc.) from a central office to each faculty or school which had academic responsibility for such courses. Such a practice was adopted at several institutions in the 1970 s as a partial response to temporary declines in full-time enrolment. Integration of day-time and evening hour courses was viewed as one strategy for coping with lower numbers of full-time students (Oliver, 1973). Other institutions maintained a more coordinated approach to the provision of evening credit courses for part-time students. Coordination took the form of maintaining a separate administrative unit for the organization and scheduling of courses or otherwise designating specific responsibility to a university sub-unit, rather than leaving the responsibility to faculties at large.

Longitudinal data from seven universities are examined to develop some preliminary conclusions on the effects of these two different approaches on the broad goal of access. Additionally, the paper describes some existing practices and administrative conditions which appear either to constrain or to encourage access of part-time students.

The study is exploratory rather than definitive and is intended to stimulate further attention to the topic. As several Canadian universities are currently considering the decentralization of specialized sub-units such as summer sessions, results may have utility for university practice.

\section{Method}

The institutions surveyed in this study were: The University of Victoria, the University of British Columbia, the University of Calgary, the University of Alberta, the University of Saskatchewan, the University of Manitoba, and the University of Western Ontario. These universities were selected for two reasons. They constituted a convenience sample for the authors of the study. In addition they are large institutions $(13,000+$ students) and reside in large urban centres $(200,000+$ population). It was recognized that focussing on a group of middle-size to large institutions located primarily in Western Canada limited 
findings. However, because the study was exploratory, this limitation was accepted. The general size of universities studied and their location in large urban centres add to the understanding of practices regarding access, because the majority of Canadian adults reside in settings similar to those served.

The data collected in the study were both empirical and impressionistic. A set of questions was distributed to each institution (Appendix A) which determined which institutions had decentralized their program of evening/weekend courses and requested comparative data on part-time enrolments and evening/weekend course offerings. These data were primarily intended to explore whether the numbers of evening/weekend courses had increased at a rate consistent with the rate of increase in part-time students following the decentralization of the program of evening/weekend courses. A follow-up questionnaire (Appendix B) investigated institutional practices in regard to services provided to part-time students.

\section{Results and Discussion}

The present study provided no definitive evidence concerning the consequences of decentralization of evening/weekend courses. As Table 1 outlines, five of the seven institutions included in this study had a centrally coordinated and budgeted program of evening/weekend courses which had been decentralized. One other institution had never had a centrally coordinated evening/weekend program (i.e., the University of Saskatchewan) and one continues to have a centrally coordinated program (i.e., the University of British Columbia). Of the five institutions which decentralized their evening/weekend courses, there is not a consistent pattern reflecting either a resultant decrease or a less than appropriate level of increase in the availability of evening/weekend course offerings. Three of the five institutions had a rate of increase in the numbers of part-time students which outstripped the rate of increase in evening/weekend course offerings. The other two institutions experienced a greater rate of increase in the evening/weekend course offerings than the increase in part-time students.

Many variables confound attempts to isolate the effects of decentralization. Summer session, inter-session and distance education programs also have an effect on access. Further, several institutions studied adopted compensatory strategies and practices to facilitate part-time study which may have served to ameliorate some of the effects of decentralization. It is also recognized that many part-time students attend day classes and many students alternate between full and part-time status during progress toward a degree (Devlin, 1989). Conclusions about access based on evening sessions alone must be qualified. 
Table 1

A Comparison of Full Course Equivalent (FCE) Courses offered and the Number of Part-Time Undergraduate Students Enrolled

\begin{tabular}{|c|c|c|c|c|c|c|c|}
\hline Institution & $\begin{array}{l}\text { Year In } \\
\text { Which } \\
\text { Decen- } \\
\text { tralization } \\
\text { Occurred }\end{array}$ & $\begin{array}{l}\text { FCE } \\
\text { Courses } 1 \\
\text { Offered In } \\
\text { Academic } \\
\text { Year Prior } \\
\text { To Decen- } \\
\text { tralization }\end{array}$ & $\begin{array}{l}\text { FCE } \\
\text { Courses } 1 \\
\text { Offered In } \\
1988-89 \\
\text { Academic } \\
\text { Year }\end{array}$ & $\begin{array}{l}\text { Percentage } \\
\text { Change In } \\
\text { FCE Courses } 1 \\
\text { Offered }\end{array}$ & $\begin{array}{l}\text { Number Of } \\
\text { Part-Time } \\
\text { Undergraduate } \\
\text { Students Enrolled } \\
\text { In Academic } \\
\text { Year Prior To } \\
\text { Decentralization }\end{array}$ & $\begin{array}{l}\text { Number Of } \\
\text { Part-Time } \\
\text { Undergraduate } \\
\text { Students Enrolled } \\
\text { In 1988-89 } \\
\text { Academic Year }\end{array}$ & $\begin{array}{l}\text { Percentage } \\
\text { Change In } \\
\text { Number Of } \\
\text { Part-Time } \\
\text { Undergraduate } \\
\text { Students }\end{array}$ \\
\hline $\begin{array}{l}\text { University of } \\
\text { Victoria }\end{array}$ & 1967 & 36 & 91 & $153 \%$ & 480 & 4081 & $750 \%$ \\
\hline $\begin{array}{l}\text { University of } \\
\text { Manitoba }\end{array}$ & 1973 & 139.5 & 218 & $56 \%$ & 3707 & 6522 & $76 \%$ \\
\hline $\begin{array}{l}\text { University of } \\
\text { Western Ontario }\end{array}$ & 1973 & 67 & 119 & $70 \%$ & 2500 (est.) & 3600 (est.) & $40 \%$ (est.) \\
\hline $\begin{array}{l}\text { University of } \\
\text { Saskatchewan }\end{array}$ & $\mathrm{n} / \mathrm{a}^{2}$ & $\mathrm{n} / \mathrm{a}^{2}$ & 119.5 & $\mathrm{n} / \mathrm{a}^{2}$ & $\mathrm{n} / \mathrm{a}^{2}$ & 3684 & $\mathrm{n} / \mathrm{a}^{2}$ \\
\hline $\begin{array}{l}\text { University of } \\
\text { Alberta }\end{array}$ & 1971 & 86 & 217 & $152 \%$ & 1869 & 4186 & $124 \%$ \\
\hline $\begin{array}{l}\text { University of } \\
\text { Calgary }\end{array}$ & 1978 & 188 & 204.7 & $9 \%$ & 2993 & 4288 & $43 \%$ \\
\hline University of & $n / a^{3}$ & $n / a^{3}$ & 266 & $n / a^{3}$ & $\mathrm{n} / \mathrm{a}^{3}$ & 2838 & $\mathrm{n} / \mathrm{a}$ \\
\hline
\end{tabular}

British Columbia

2 The University of Saskatchewan has never had a centrally coordinated and centrally budgetted administrative model for the offering of evening/weekend courses. Budgetary control and course scheduling has always been decentralized to academic departments and non-departmentalized colleges.

3 The University of British Columbia continues to employ a centrally administered program of evening/weekend courses. The Office of Extra-Sessional Studies coordinates both evening/weekend courses and Summer Session courses. 
Nonetheless, it is important to address such questions as universities attempt to develop new structures and processes to meet contemporary needs. In particular, when institutions consciously change administrative policies or procedures to achieve a desired end, the evaluation of outcomes such as the present effort seems warranted. As a minimum, current results do not provide evidence that a deliberate change to a more decentralized model for the organization of evening sessions resulted in greater access than would have occurred without such a change.

A particular value of the present study lies in its identification of specific institutional practices which have been adopted by some universities and which appear to have value in accommodating the needs of part-time students. The identification and discussion of these practices should prove useful to other institutions which are concerned about recruiting part-time students and responding to their special needs. This should also be useful in considering the implications of the possible decentralization of summer studies programs. Accordingly, the next section provides a review of these institutional practices. A summary of these practices is presented in Table 2.

\section{Context of the Study}

This exploratory study identified a number of definitional complexities and varied institutional practices which limit the conclusions which can be drawn from the data collected. As they will serve to provide guidance for future research in this area, they are described below in some detail.

1) There is a lack of uniformity among institutions in the operational definition of what constitutes part-time study. This is not surprising since there are various views of what the term "part-time student" implies. In its most restricted sense it includes only those persons who are not able to attend classes offered during the usual working day (i.e., 9 a.m. to 5 p.m.) during the usual working week (i.e., Monday-Friday). Such persons are typically restricted to evening and weekend classes (excluding distance education courses). On the other hand, many part-time students do attend day-time classes and as Devlin (1989) noted, there are many students who alternate between full-time and part-time attendance. Stagen (1984) makes a similar distinction between those part-time students who are employed full-time and are restricted thereby to part-time study from those who were previously full-time students and who now elect to study part-time. He argues "while they have a legitimate claim on postsecondary policy and resources, they represent a less complex set of considerations that impinge on the design of programs and admission than persons who choose to 
Table 2

A Comparison of Selected Institutional Services and Practices Provided for Part-time Students

\begin{tabular}{|c|c|c|c|c|c|c|}
\hline Institution & $\begin{array}{l}\text { Separate } \\
\text { publication } \\
\text { listing } \\
\text { evening/ } \\
\text { weekend } \\
\text { course } \\
\text { offerings }\end{array}$ & $\begin{array}{l}\text { Central office } \\
\text { providing } \\
\text { advising/ } \\
\text { information } \\
\text { services for } \\
\text { part-time } \\
\text { students? }\end{array}$ & $\begin{array}{l}\text { What degrees } \\
\text { can be } \\
\text { completed } \\
\text { entirely by } \\
\text { means of } \\
\text { part-time } \\
\text { study? }\end{array}$ & $\begin{array}{l}\text { Are there } \\
\text { publications } \\
\text { (other than } \\
\text { timetables } \\
\text { specifically } \\
\text { produced for } \\
\text { part-time } \\
\text { students? }\end{array}$ & $\begin{array}{c}\text { Is there a } \\
\text { 3-5 year } \\
\text { timetable } \\
\text { produced } \\
\text { which lists } \\
\text { future course } \\
\text { for evening/ } \\
\text { weekend courses }\end{array}$ & $\begin{array}{l}\text { Is there a } \\
\text { a part-time } \\
\text { student } \\
\text { association? }\end{array}$ \\
\hline $\begin{array}{l}\text { University of } \\
\text { Victoria }\end{array}$ & No & No & B.A. & No & No & No \\
\hline $\begin{array}{l}\text { University of } \\
\text { Manitoba }\end{array}$ & No & No & $\begin{array}{l}\text { B.A. } \\
\text { M.B.A. }\end{array}$ & No & No & No \\
\hline $\begin{array}{l}\text { University of } \\
\text { Western Ontario }\end{array}$ & Yes & Yes & B.A. & Yes & No & Yes \\
\hline $\begin{array}{l}\text { University of } \\
\text { Saskatchewan }\end{array}$ & No & No & None & Yes & No & No \\
\hline $\begin{array}{l}\text { University of } \\
\text { Alberta }\end{array}$ & Yes & No & None & Yes & No & No \\
\hline $\begin{array}{l}\text { University of } \\
\text { Calgary }\end{array}$ & No & No & $\begin{array}{l}\text { M.B.A. } \\
\text { M.Ed. }\end{array}$ & No & No & No \\
\hline $\begin{array}{l}\text { University of } \\
\text { British Columbia }\end{array}$ & Yes & Yes & $\begin{array}{l}\text { B.A. } \\
\text { B.Sc. }\end{array}$ & No & No & No \\
\hline
\end{tabular}


enter part-time study because they cannot afford to leave full-time employment." (p. 26)

Additionally, there is a lack of consistency in the definition of evening/weekend courses. For example, the University of British Columbia includes courses which commence at or after 4:30 p.m. The University of Calgary considers courses which commence at or after 5:00 p.m. as evening courses. Other institutions have their evening courses commencing at 6:30 p.m. or 7:00 p.m. In most institutions there was not a single time at which such courses commenced. In particular, courses offered by the faculties of Education frequently commenced at 4:30 p.m., while courses in other faculties typically commenced at a later time.

2) The number of part-time students and the number of evening/weekend courses are variables which are clearly not independent of each other. In particular, it is possible that the number of part-time students would be greater if there were increased availability of evening/weekend courses.

3) There is insufficient information available to determine what demand exists for evening/weekend courses. In particular, there is a paucity of information concerning how many potential part-time undergraduate students are only able to attend such courses as a result of family, employment, and other constraints. Carp, Peterson, and Roelfs (1974) reported that over three-fourths of American adults say that they would like to continue their learning but less than one-third are presently doing so. It is possible that there is a significant audience of prospective students who would attend if an adequate range of courses (and programs) were provided at times convenient for them.

4) There is insufficient information regarding who attends existing evening/weekend courses. What proportion of these students can only attend such courses as a result of other commitments which restrict access to day-time classes? Although the absolute number of courses offered in the evening hours has increased significantly over the past twenty years, does this reflect increasing participation (and access) by part-time students who cannot attend day-time classes? Alternately it may be that many students who attend evening/weekend courses are students who are concurrently registered in day-time courses. Enrolments of both full-time and part-time undergraduate students at Canadian universities have continued their steady increase following the decreases of the early 1970s (Statistics Canada, 1989). Nonetheless, Canadian universities experienced severe financial constraints through the 1970 s and 1980s. Capital funding to permit construction of new buildings, and especially additional instructional space, has not kept pace with enrolment growth. Accordingly, it is 
possible that the increased number of evening/weekend courses may accommodate a significant number of students who are concurrently registered in daytime courses. They may not, in other words, reflect increased participation by part-time students who cannot attend day-time classes.

5) Over the past twenty years since many institutions decentralized their program of evening/weekend courses, there have been many other changes in institutional practices. For example, many institutions have significantly increased the provision of distance education courses. In addition, new institutions, such as Athabasca University have provided alternative opportunities to on-campus part-time study. Shale (1982) and Paul (1986) note that Athabasca University derives a significant proportion of its students from the urban centres of Calgary and Edmonton which have large universities. Accordingly, it is likely that a significant number of students who might otherwise be seeking evening/weekend courses at their local universities are accommodated through distance education programs. These developments and others reported in the previous section confound any attempt to isolate the consequences which can specifically be associated with the decentralization of evening course offerings.

\section{Institutional Practices Which Accommodate Part-Time Students}

1) One of the problems which confront many potential part-time undergraduate students confront is knowing how to approach the institution. Those students who have had prior experience with universities are more likely to know how to proceed, but not those who lack such experience. Some universities explicitly identify a unit which is responsible for part-time students. For example, the University of Western Ontario has the Faculty of Part-Time and Continuing Education. Such identification provides a clear point of entry for prospective part-time students. In addition, and perhaps more importantly, it provides an implicit invitation to prospective part-time students. Additionally, however, the institution must commit resources to support any unit which will be assigned such responsibility. At universities such as Western Ontario and Manitoba there are staff assigned to provide academic advising to support parttime students. But many continuing education units are under increasing pressure to be self-supporting financially. Under such pressure it is less likely that the continuing education units would be able to accommodate such responsibilities.

2) Many prospective part-time students lack the confidence and the skills required to enrol and to succeed. A number of institutions provide study skills 
programs explicitly organized for the prospective part-time student. A related non-credit program which is provided by some institutions is a career planning or career re-entry course.

3) A number of universities provide some degree of support for part-time and/or mature student associations. These associations can offer peer support, access to information, and a springboard for lobbying for institutional change or provision of services of particular importance to part-time students. In some institutions, the Continuing Education unit or the Counselling Services unit provides an organizational locus for such associations.

4) None of the institutions surveyed presently produces a three to five year timetable of evening and weekend courses to enable part-time students to plan their selection of courses. While there are obvious difficulties in producing long-range schedules, the availability of such information may be particularly important for the part-time student who cannot attend day-time courses and who is therefore restricted to a much more limited set of course offerings. The University of Manitoba did publish a five year timetable of selected evening hour courses but this practice was discontinued after the decentralization occurred. While the timetable included a minority of the actual offerings, it sought to identify core or required courses for many programs of study.

5) A number of institutions have adopted innovative strategies for timetabling courses. For example, some courses will be provided in an intensive format over several weekends. Other courses are compressed into intensive two or three week sessions. While some debate the academic merits of such accommodation (Holtzclaw, 1988), there is no doubt that it provides advantages in terms of increased access. Despite problems of definition, the substantive importance of evening sessions as a vehicle for academic access is illustrated by recent American findings. Of 6.2 million adults ( 25 or older) engaged in degree credit study in 1988, 53\% were studying in courses offered after 4:00 p.m. or on weekends (College Board, 1988, p. 44). The current adult "share" of American higher education now exceeds $45 \%$. These data appear to confirm that evening, weekend and other special sessions are important to understanding and measuring of the concept of "openness."

6) As noted previously, the provision of distance education courses is an important institutional response to accommodating part-time students. There is substantial evidence, however, that distance education programs are not as attractive to many part-time students as regular classroom instruction (e.g., Carp, Peterson, \& Roelfs 1974; De Goede \& Hoksbergen, 1978; Thompson, 1990; Waniewicz, 1976). Accordingly, such programs may provide a 
supplementary mode of study and may provide access to required courses not available as on-campus or evening/weekend courses when they are needed. Nonetheless, they may not be an acceptable substitution for face-to-face instruction as the primary mode of instruction for many students. The "program approach" employed by the University of Saskatchewan provides an integrated model whereby various course delivery options are coordinated and their combined availability made known to prospective students (James \& Wagner, 1989).

7) In general, there is a paucity of information explicitly prepared for parttime students. Information which encourages prospective students to consider part-time study and which makes them aware that degrees can be earned entirely through part-time study is not widely available. Ruyle and Geiselman (1974) report that in three out of four American colleges and universities it is possible for students to earn undergraduate degrees by means of part-time study (p. 56). Nonetheless, they also report that only a little more than one-half of the institutions they surveyed publicized such opportunities to prospective students (p. 91). Cross (1982) reported:

About one fourth of potential learners confess that they do not know where to go or whom to ask to get information about learning opportunities ... The lack of specific information about educational opportunities presents an obstacle to learning participation for perhaps 15 to 30 percent of potential learners (p. 126).

In some institutions there are degree programs which can be completed entirely by means of part-time study. For example, the part-time M.B.A. degree at the University of Manitoba communicates an explicit commitment to the part-time student that the necessary evening courses will be available and that all requirements for the program can be met by part-time study. In many cases, however, there is no such commitment expressed nor availability made known.

\section{Recommendations for Further Research}

The number of undergraduate students who register for part-time study in Canadian universities has been faithfully recorded and reported for many years. What is not known is the number of potential part-time students who do not enrol because of actual and/or perceived restrictions on access to part-time study. In addition, we need to learn more about the specific needs of such potential students and the barriers which prevent their participation. The following questions are proposed for further research: 
1) We need to learn more about current part-time students. For example, what proportion of them are restricted to registering in evening/weekend courses?

2) What problems are faced by current part-time students, especially in regard to institutional practices which limit access and completion of studies?

3) What number of potential students would participate in part-time study if there were increased access and availability of courses? In other words: Is there a problem, and if so, what is its magnitude?

4) If there is a significant pool of potential part-time undergraduate students, then what do universities need to do to attract and better serve them? To what extent do we need to change institutional practices and to what extent do we need only make potential students more aware of existing opportunities?

\section{Conclusion}

In the process of assembling and reviewing the information presented in this paper the authors were inclined to the view that part-time students are not particularly well-served by Canadian universities. In particular, those persons whose personal circumstances preclude full-time attendance and who are unable to attend day-time classes seem especially disenfranchised. At the same time, we must admit that the data required to support that view are fragmentary and, in many respects, inconclusive. It appears, however, that many institutions are tolerant of part-time students but make little attempt to recruit them actively (Holtzclaw, 1988). One wonders how many more part-time students might enrol in our universities were such recruitment to occur. Abner and Tacon (1990) observe that Atkinson College has not attracted the type of part-time student that had been the original target audience for the College. A benign but passive approach to recruitment and admissions has resulted in the enrolment of a much higher proportion of "traditional" students. The authors propose that a more aggressive and deliberate approach to recruitment is necessary to attract the non-traditional student. The incentive to adopt such approaches is muted when enrolment continues to be at present high levels. Nonetheless, we have learned that enrolment patterns are cyclical. There is a growing number of institutions and organizations which provide degree completion programs (Eurich, 1985). Some of them are especially accommodating of the needs and circumstances of 
part-time students. One Hong Kong based institute proposes to offer the Master of Business Administration degree to people living in Vancouver with "no interference with full-time employment" and "monthly week-end classes." (Vancouver Sun, June 9, 1990)

Demographic projections of university enrolments have proven to be of questionable value. Nonetheless, there are predictions that the traditional student body - those 18-22 years old who predominantly register for full-time study in day-time courses - will decline in the 1990s (Bélanger, Lynd, \& Mouelki, 1982; Levine, 1990). Accordingly, it would serve us well to undertake further research to learn more about the phenomenon of part-time study. Apart from the motivation of intellectual curiosity, it may well be that enlightened self-interest will promote such research. As Apps (1988) and many others have noted, universities are being called upon to be more responsive to the needs of society and those universities which fail to respond may find that there is a high price to pay.

\section{APPENDIX A}

Questions for survey on accessibility for part-time students

1. What was the last full academic year (i.e., September-April) in which your University had a centrally coordinated and centrally budgeted administrative model for the offering of evening hour/weekend courses in the regular session?

2. How many full course equivalent (f.c.e.) units (by faculty) were offered in evening hour and weekend courses in that last (academic) year in which a centrally coordinated model existed?

3. How many f.c.e. units (by faculty) were offered in evening/weekend courses in the 1988-89 academic year?

4. What degree programs (B.A., B.Ed., etc.) could be entirely completed by means of regular session evening hour/weekend courses only in the last year in which your University had a centrally administered model (i.e, not including Summer Studies courses)? What degree programs can be entirely completed by hour/evening courses at the present time?

5. Does your University have a centrally administered model for summer studies course offerings? If yes:

a) How many f.c.e. units (by faculty) were offered in the Summer Studies immediately preceding the last academic year in which you employed a centrally coordinated model for evening/week- 
end courses (e.g., if the last year in which evening hour/weekend courses were centrally administered was 1972-73, then please use the data for the 1972 Summer Studies).

b) How many f.c.e. units (by faculty) were offered in the 1988 Summer Studies program?

c) What degree programs (i.e., B.A., B.Ed., etc.) could be entirely completed by means of Summer Studies courses only (i.e., not including evening/weekend courses in the regular session) in the Summer Studies program identified by question \#5a above. What degree programs can be completed by Summer Studies courses only in the 1988 Summer Studies program?

6. How many students were registered as part-time students at your University for each of the following sessions:

a) The regular academic year identified in response to question \#1.

b) The Summer Studies session identified in response to question \#5a.

c) The 1988-89 regular academic session.

d) The 1988 Summer Studies program.

\section{APPENDIX B}

\section{Supplementary questions for survey of part-time students}

\section{Present Practices}

1. Does your university publish a statement (calendar/and or newspaper ads) of evening/weekend courses? If so, who does it?

2. Does your university have an explicitly identified central office to serve part-time students (e.g., in phone directory). If so, what is it called and what services does it offer? Are there other services especially aimed at part-time students which are not centrally coordinated?

3. Does your university publish any materials which are especially and explicitly designed for part-time students? If so, who does it?

4. Does your university develop and publish a schedule of future course offerings for evening/weekend courses (e.g., 3-5 year schedule)? If so, who does it?

5. Do your part-time students all register with a particular faculty?

6. Does your university explicitly identify any programs which can be entirely completed by part-time study? If yes, what programs and who coordinates?

7. Does your university have a part-time and/or mature students association? If so, what does it (they) do and what organizational linkage do they have? 
8. What, if any, services were previously available to part-time students (when centrally coordinated) which are no longer?

$$
\begin{aligned}
& \text { e.g. - identified programs } \\
& \text { - coordination of information } \\
& \text { - easy identification for entry } \\
& \text { - long term course scheduling } \\
& \text { - advising/course scheduling }
\end{aligned}
$$

9. Do you have any institutional reports/studies which especially relate to part-time studies/students?

\section{References}

Abner, A., \& Tacon, P. (1990). A profile of the adult part-time student. A paper presented at the Annual Conference of the Canadian Society for the Study of Higher Education, Victoria, B.C.

Anisef, P. (1985). Accessibility to postsecondary education in Canada: A review of the literature. Ottawa: Secretary of State.

Anisef, P. (1989). Studying part-time in Canada's universities: A social change perspective. The Canadian Journal of Higher Education, XIX (1), 11-28.

Apps, J.W. (1988). Higher education in a learning society. San Francisco: Jossey-Bass.

Bélanger, R., Lynd, D., \& Mouelki, M. (1982). Part-time degree students: Tomorrow's majority. Ottawa: Minister of Supply and Services Canada.

Cameron, K. (1978). Measuring organizational effectiveness in institutions of higher education. Administrative Science Quarterly, 23, 604-632.

Campbell, D. (1984). The new majority: Adult learners and the university. Edmonton: The University of Alberta Press.

Canadian Organization of Part-time University Students. (1987). Part-time university students in Canada: An analysis of the 1974-75 and 1983-84 postsecondary student surveys. Prepared by P. Anisef, York University, North York, Ontario.

Carp, A., Peterson, R., \& Roelfs, P. (1974). Adult learning interests and experiences. In K.P. Cross, J.R. Valley \& Associates (Eds.), Planning non-traditional programs. San Francisco: Jossey-Bass, pp. 11-52.

College Entrance Examination Board. (1988). How Americans in transition study for college credit. New York.

Cross, K.P. (1982). Adult leamers: Characteristics, needs, and interests. In R.E. Peterson and Associates (Eds.), Lifelong learning in America. San Francisco: Jossey-Bass.

De Goede, M.P.M., \& Hoksbergen, R.A.C. (1978). Part-time education at tertiary level in the Netherlands. Higher Education, 7, 443-455.

Devlin, L. (1989). Part-time students: A closer look. Canadian Journal of University Continuing Education, 15 (1), 29-38.

Eurich, N. (1985). Corporate classrooms: The learning business. Princeton, N.J.: Carnegie Foundation for the Advancement of Teaching. 
Fortin, M. (1987). Accessibility to and participation in postsecondary education. In Proceedings of the National Forum on postsecondary education (pp. 70-72). Halifax, Nova Scotia, Canada: Institute for Research on Public Policy.

Holtzclaw, L.R. (1988). Flexible admission practices for adult learners. Lifelong Learning, 11 (6), 9-11.

James, G.G., \& Wagner, R.M.K. (1989). Enhancing access to university in times of burgeoning enrolments: A comparison of conventional full-time on-campus students with the new "University transfer" or program approach students. A paper presented at the Canadian Society for the Study of Higher Education, Laval University, Quebec City.

Konrad, A.G., \& McNeal, J. (1984). Goals in Canadian universities. The Canadian Journal of Higher Education, XIV (1), 31-40.

Levin, J.S., \& Dennison, J.D. (1989). Responsiveness and renewal in Canada's community colleges: A study of organizations. The Canadian Journal of Higher Education, $X I X(2), 41-57$.

Levine, A. (1990). Defying demographics. Currents, 16 (6), 26-30.

Lynton, E.A., \& Elman, S.E. (1987). New priorities for the university. San Francisco: Jossey-Bass.

MacInnes, C.M. (1963). Canadian adult education in 1925. In J.R. Kidd (Ed.), Learning and society: Readings in Canadian adult education. Toronto: Canadian Association for Adult Education, (pp. 4-21).

Neilson, A.W., \& Gaffield, C. (Eds.). (1986). Universities in crisis: A mediaeval institution in the twenty-first century. Montreal: Institute for Research on Public Policy.

Oliver, M. (1973). Factors reshaping the financing of higher education in the 1970's. STOA, 3 (2), 105-112.

Paul, R. (1986). Athabasca University. In D. Kaufman and I. Mugridge (Eds.), Distance education in Canada. Beckenham, Kent: Croom Helm.

Ruyle, J., \& Geiselman, L.A. (1974). Non-traditional opportunities and programs. In K.P. Cross, J.R. Valley, \& associates (Eds.), Planning non-traditional programs. San Francisco: Jossey-Bass.

Secretary of State. (1989). Open learning and distance education in Canada. Canadian Studies Resource Guide, Open Learning Agency of B.C. Ottawa: Ministry of Supply and Services.

Segal, B. (1990). Retrospective on the Forum. The Canadian Journal of Higher Education, XX (1), 1-3.

Shale, D. (1982). Athabasca University, Canada. In G. Rumble \& K. Harry (Eds.), The distance teaching universities. London: Croom Helm.

Stagen, D. (1984). Accessibility and the demand for university education. A discussion paper prepared for the Commission on the Future Development of the Universities of Ontario.

Statistics Canada. (1983). Historical Statistics of Canada, (2nd. ed.). (Catalogue No. C311-516E). Ottawa: Ministry of Supply and Services Canada. 
Statistics Canada. (1989). Canada Yearbook 1990. Ottawa: Ministry of Supply and Services Canada.

Thompson, G. (1990). How can correspondence-based distance education be improved? A survey of attitudes of students who are not well disposed toward correspondence study. Journal of Distance Education, 4 (2), 53-65.

Tight, M. (1982). Part-time degree level study in the United Kingdom. Report of the Advisory Council for Adult and Continuing Education. London, England: ACACE.

Waniewicz, I. (1976). Demand for part-time learning in Ontario. Toronto: Ontario Institute for Studies in Education. 